\title{
Eksplorasi bakteri gram negatif endofit tanaman kunyit (Curcuma longa L.) yang memiliki kemampuan Quorum Quenching
}

\author{
Meika Meidina Yuanita ${ }^{1}$, Eka Ardiani Putri ${ }^{2}$, Mahyarudin $^{3}$, Mardhia $^{3}$, Ambar Rialita $^{4}$ \\ 1. Program Studi Kedokteran, Fakultas Kedokteran, Universitas Tanjungpura, Kalimantan Barat; 2. \\ Departemen Kesehatan Masyarakat, Program Studi Kedokteran, Fakultas Kedokteran, Universitas \\ Tanjungpura, Kalimantan Barat; 3. Departemen Mikrobiologi, Program Studi Kedokteran, Fakultas \\ Kedokteran, Universitas Tanjungpura, Kalimantan Barat; 4. Departemen Dermatovenerologi, \\ Program Studi Kedokteran, Fakultas Kedokteran, Universitas Tanjungpura, Kalimantan Barat
}

Korespondensi: Mahyarudin; email: mahyarudin@medical.untan.ac.id

\begin{abstract}
Abstrak
Tujuan: Penelitian ini bertujuan untuk mengetahui karakter bakteri Gram negatif endofit tanaman kunyit yang memiliki kemampuan Quorum Quenching (QQ). Metode: Bakteri Gram negatif endofit tanaman kunyit diisolasi, dimurnikan, dan disubkultur pada media NA dengan metode cawan gores. Uji QQ dilakukan dengan metode disc diffusion untuk mengukur pembentukan zona hambat pada bakteri uji Chromobacterium violaceum. Bakteri yang memiliki kemampuan QQ dikarakterisasi berdasarkan morfologi koloni, morfologi sel dan aktivitas biokimia. Hasil: Sebanyak 21 isolat bakteri endofit berhasil diisolasi dan dimurnikan dari tanaman kunyit dan 14 isolat diantaranya merupakan bakteri Gram negatif. Semua isolat bakteri Gram negatif endofit memiliki kemampuan QQ yang berkisar antara 6,5-13,5 mm. Satu isolat yang memiliki kemampuan QQ paling besar adalah isolat 6 dengan hasil identifikasi termasuk ke dalam genus Pseudomonas. Simpulan: Bakteri Gram negatif endofit tanaman kunyit yang memiliki kemampuan QQ paling potensial adalah genus Pseudomonas. Kata kunci: bakteri gram negatif endofit; Curcuma longa L.; quorum quenching; Chromobacterium violaceum
\end{abstract}

\begin{abstract}
Objectives: This study aimed to determine the characteristics of Gram-Negative endophytic bacteria that had Quorum Quenching (QQ) abilities. Methods: Turmeric plant's endophytic bacteria were isolated, purified and subcultured on NA medium by streak plate method. QQ ability test was carried out using disc diffusion method to measure the color inhibition zone of Chromobacterium violaceum. Bacteria that had QQ ability were characterized based on colony morphology, cell morphology and biochemical activities. Results: A total of 21 endophytic bacteria were isolated and purified from turmeric plant and 14 of them were Gram-negative bacteria. All Gram-negative endophytic bacteria isolates had QQ ability ranged from 6.5-13.5 $\mathrm{mm}$. An isolate with the most potential QQ ability was Isolate 6 which had been identified belongs to genus Pseudomonas. Conclusions: Gram-negative bacteria of turmeric plant which had the most potential QQ ability is genus Pseudomonas
\end{abstract} Keywords: Gram-negative endophytic bacteria; Curcuma longa L.; quorum quenching; Chromobacterium violaceum 


\section{PENDAHULUAN}

Resistensi mikroorganisme menjadi salah satu masalah yang terus meningkat. ${ }^{1}$ Tingginya masalah resistensi mikroorganisme terhadap antibiotik, maka akhir-akhir ini mulai dilakukan penelitian untuk mengatasi infeksi menggunakan senyawa yang dapat menurunkan perkembangan mikroorganisme. Salah satunya adalah dengan menggunakan metode penghambatan komunikasi antar mikrob/penghambatan quorum sensing (QS).

Quorum sensing (QS) merupakan proses dimana bakteri merespons informasi dari sel yang lain. Mekanisme komunikasi interseluler ini dimediasi oleh extracellular signaling molecules atau yang biasa disebut dengan autoinducers (Als), yang diakumulasi di lingkungan sekitar sel. ${ }^{2-6}$ Sistem QS umumnya berhubungan dengan simbiosis dan patogenesis dari bakteri. Bakteri akan mengekspresikan faktor virulensinya pada saat kepadatan populasinya sudah mencapai ambang batas tertentu. Hal ini dilakukan untuk menghindari terprovokasinya sistem imun inang yang terlalu dini sehingga sistem imun dapat mencegah infeksi dengan cepat pada saat bakteri tersebut masih sedikit. ${ }^{7}$ Dua sinyal QS yang paling luas dipelajari adalah AHL (Acylhomoserine lactone) dan peptida. AHLs digunakan pada bakteri Gram negatif sedangkan peptida digunakan pada bakteri Gram positif. ${ }^{8}$ Satu di antara bakteri-bakteri Gram negatif yang memanfaatkan QS sebagai media komunikasinya adalah Chromobacterium violaceum, bakteri yang terdistribusi secara luas pada lingkungan akuatik alami. ${ }^{9}$

Quorum sensing (QS) pada C. violaceum terdiri dari Luxl/LuxR homolog Cvil/CviR, yang dapat mengendalikan virulensi dan produksi dari ciri-ciri fenotip seperti pembentukan pigmen ungu. ${ }^{10}$ Penghambatan produksi violacein sebagai pigmen ungu dapat dilihat sebagai penghambatan dari mekanisme QS atau yang disebut dengan quorum quenching (QQ). Hal ini menyebabkan C. violaceum sering digunakan sebagai indikator quorum sensing. Senyawa yang memiliki efek $\mathrm{QQ}$ akan menghambat pembentukan dari pigmen ungu bakteri tersebut. Senyawa yang berpotensi sebagai $\mathrm{QQ}$ dapat ditemukan pada tanaman kunyit, yaitu kurkumin.

Kunyit (Curcuma longa L.) merupakan salah satu tanaman yang sering digunakan oleh masyarakat sebagai bumbu masakan, pewarna alami dan bahan baku obatobatan. Tanaman ini mengandung senyawa kurkumin yang berpotensi sebagai antioksidan dan memiliki kemampuan QQ. ${ }^{11-14}$ Efek-efek tersebut diketahui dapat dihasilkan oleh mikrob endofit pada tanaman kunyit.

Mikrob endofit pada tanaman dapat menghasilkan senyawa yang dapat berguna sebagai anti mikrob, anti kanker, dan anti oksidan. ${ }^{15}$ Bakteri endofit merupakan mikroorganisme simbiotik yang hidup di dalam jaringan tanaman dan tidak menimbulkan efek negatif pada tanaman inangnya. ${ }^{16}$ Bakteri endofit pada tumbuhan diketahui dapat menghasilkan 
senyawa bioaktif yang dapat menghambat QS.

Pada penelitian sebelumnya telah dilakukan eksplorasi keragaman bakteri endofit tanaman kunyit putih yang memiliki kemampuan anti mikrob yang hasilnya menunjukkan bahwa bakteri endofit tanaman kunyit putih didominasi oleh bakteri Gram negatif dan persentase ditemukannya bakteri endofit pada bagian rimpang menunjukkan angka paling tinggi sebelum daun dan batang. ${ }^{17}$ Pada penelitian lainnya juga telah dilakukan isolasi dan identifikasi kapang endofit dari tanaman kunyit sebagai penghasil

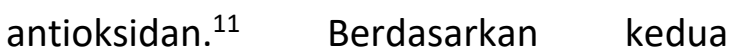
penelitian tersebut belum ada yang mengeksplorasi bakteri endofit tanaman kunyit yang memiliki efek QQ. Maka dari itu peneliti tertarik untuk melakukan penelitian mengenai eksplorasi bakteri Gram negatif endofit pada tanaman kunyit yang berpotensi sebagai $Q Q$ yang diharapkan dapat menjadi dasar untuk penelitian lebih lanjut oleh peneliti selanjutnya di masa mendatang.

\section{METODE}

Rimpang kunyit diperoleh dari Jalan Danau Sentarum, Pontianak, Kalimantan Barat. Sterilisasi permukaan rimpang kunyit dilakukan untuk mengeleminasi bakteri selain bakteri endofit. Isolasi bakteri endofit dilakukan dengan metode tanam langsung dan pemurnian dilakukan dengan metode cawan gores pada suhu ruang selama 24-48 jam. Bakteri uji C. violaceum didapatkan dari Departemen Parasitologi
Universitas Indonesia. Sebelum digunakan bakteri uji diremajakan menggunakan media NA dengan metode cawan gores.

Metode pengujian secara kualitatif untuk mendeteksi adanya kemampuan QQ dapat dilakukan dengan metode disc diffusion. Isolat bakteri Gram negatif ditumbuhkan dalam media NB dan diaduk menggunakan shaker selama 18 jam (sampai nilai Optical Density (OD) mencapai 0,5). Setelah OD mencapai 0,5 kultur di-sentrifugasi dengan kecepatan 10.000 rpm selama 10 menit. Supernatan yang terbentuk diteteskan sebanyak $100 \mu \mathrm{l}$ pada kertas cakram dan diletakkan di atas permukaan media NA semi solid yang mengandung $1 \% \quad C$. violaceum. Setelah itu inkubasi pada suhu ruang selama 24 jam. QQ ditandai dengan adanya zona yang tidak berwarna ungu di sekitar kertas cakram. ${ }^{18}$ QQ ditandai dengan tidak terbentuknya pigmen pada media. Pengujian dapat dilakukan dengan mengukur diameter zona hambat dengan menggunakan jangka sorong.

Isolat bakteri yang memiliki kemampuan QQ paling potensial dikarakterisasi dan diidentifikasi secara biokimia dengan panduan Bergey's Manual of Determinative Bacteriology. ${ }^{19}$ Karakterisasi dilakukan dengan mengamati morfologi koloni, morfologi sel dan aktivitas biokimia bakteri.

\section{HASIL DAN PEMBAHASAN}

Rimpang kunyit sehat yang tidak terlalu muda maupun terlalu tua, diambil sebanyak 3 buah yang diperoleh dari Jalan Danau Sentarum, Pontianak, Kalimantan 
Barat. Sterilisasi permukaan dikonfirmasi yaitu tidak adanya bakteri yang tumbuh berhasil berdasarkan hasil yang didapat pada media NA selama 48-96 jam.

Tabel 1. Hasil Pemurnian Bakteri Gram Negatif Endofit

\begin{tabular}{ccccccc}
\hline No & Nama & \multicolumn{4}{c}{ Morfologi Koloni } & Morfologi Sel \\
& Isolat & Bentuk & Permukaan & Tepi & Warna & \\
\hline 1 & Isolat 1 & Bulat titik & Cembung & Utuh & Putih kekuningan & Basil Gram negatif \\
2 & Isolat 2 & Bulat & Timbul & Bergelombang & Putih kekuningan & Basil Gram negatif \\
3 & Isolat 3 & Irregular & Cembung & Bergerigi & Putih kekuningan & Basil Gram negatif \\
4 & Isolat 4 & Irregular & Timbul & Bergerigi & Putih kekuningan & Basil Gram negatif \\
5 & Isolat 5 & Irregular & Datar & Bergelombang & Putih kekuningan & Basil Gram negatif \\
6 & Isolat 6 & Bulat & Datar & Bergelombang & Putih kekuningan & Basil Gram negatif \\
7 & Isolat 7 & Irregular & Timbul & Bergerigi & Putih kekuningan & Basil Gram negatif \\
8 & Isolat 8 & Irregular & Timbul & Bergelombang & Putih kekuningan & Basil Gram negatif \\
9 & Isolat 9 & Irregular & Timbul & Bergelombang & Putih kekuningan & Basil Gram negatif \\
10 & Isolat 10 & Irregular & Datar & Bergerigi & Putih kekuningan & Basil Gram negatif \\
11 & Isolat 11 & Bulat & Cembung & Bergelombang & Putih kekuningan & Basil Gram negatif \\
12 & Isolat 12 & Irregular & Timbul & Bergerigi & Putih kekuningan & Basil Gram negatif \\
13 & Isolat 13 & Bulat & Timbul & Bergelombang & Putih kekuningan & Basil Gram negatif \\
14 & Isolat 14 & Bulat & Timbul & Utuh & Putih kekuningan & Basil Gram negatif \\
\hline
\end{tabular}

Tabel 2. Hasil Uji Kemampuan QQ Bakteri Gram Negatif Endofit

\begin{tabular}{ccc}
\hline No & Nama Isolat & Zona Hambat $(\mathbf{m m})$ \\
\hline 1 & Isolat 1 & 11,8 \\
2 & Isolat 2 & 10,1 \\
3 & Isolat 3 & 12,3 \\
4 & Isolat 4 & 11,1 \\
5 & Isolat 5 & 10,8 \\
6 & Isolat 6 & 13,5 \\
7 & Isolat 7 & 11,3 \\
8 & Isolat 8 & 10,8 \\
9 & Isolat 9 & 6,5 \\
10 & Isolat 10 & 6,5 \\
11 & Isolat 11 & 6,5 \\
12 & Isolat 12 & 6,5 \\
13 & Isolat 13 & 12,8 \\
14 & Isolat 14 & 8 \\
\hline
\end{tabular}

Kunyit yang telah dipotong dan diletakkan di media NA memperlihatkan adanya pertumbuhan bakteri yang tumbuh di sekitar kunyit. Setiap koloni diisolasi dan dimurnikan sehingga menghasilkan 21 isolat bakteri endofit murni dan 14 isolat diantaranya merupakan bakteri Gram negatif endofit. Isolat diberi nama menggunakan angka 1-14. Hasil pemurnian bakteri Gram negatif endofit dapat dilihat pada Tabel 1.

Hasil uji kemampuan QQ bakteri endofit Gram negatif yang dilakukan menggunakan metode difusi cakram menunjukkan bahwa semua isolat Gram negatif memiliki aktivitas $\mathrm{QQ}$ terhadap C. violaceum. Zona hambat yang terbentuk berkisar antara 6,513,5 mm. Hasil uji kemampuan QQ bakteri endofit Gram negatif terhadap $C$. violaceum dapat dilihat pada Tabel 2 .

Isolat yang memiliki zona hambat terbesar yaitu sebesar 13,5 mm merupakan Isolat 6 . Isolat 6 memiliki ciri koloni berwarna putih kekuningan, tepi bergelombang, permukaan datar dan berbentuk bulat. Morfologi sel isolat ini berbentuk basil dan merupakan bakteri Gram negatif. Zona hambat yang dihasilkan dari uji 
kemampuan QQ menggunakan bakteri ini dapat diamati dengan terlihatnya daerah yang lebih bening pada media yang sebelumnya berwarna ungu karena terdapat pertumbuhan bakteri uji $C$. violaceum. Morfologi koloni, morfologi sel dan zona hambat Isolat 6 dapat dilihat pada Gambar 1.

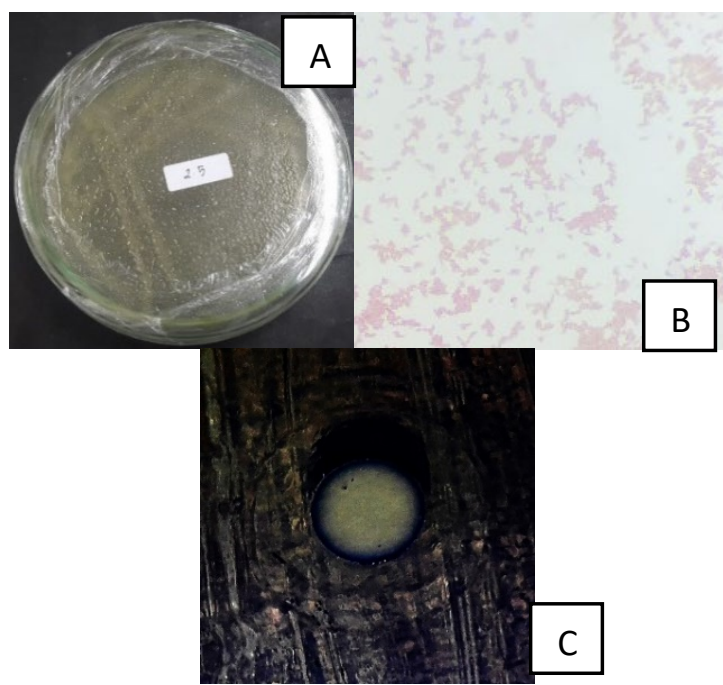

Gambar 1. A) Morfologi Koloni; B) Morfologi Sel; C) Zona Hambat Isolat 6 terhadap C. violaceum

Uji biokimia yang dilakukan pada isolat yang paling potensial atau Isolat 6 yaitu antara lain uji kebutuhan oksigen, uji motilitas, uji glukosa, uji laktosa, uji manitol, uji maltosa, uji sakarosa, uji indol, uji simon sitrat, uji oksidase, uji katalase dan uji ornitin. Hasil uji menunjukkan bakteri isolat 6 merupakan bakteri aerob, motilitas positif, glukosa negatif, laktosa negatif, manitol negatif, maltosa negatif, sakarosa negatif, indol negatif, simon sitrat positif, oksidase negatif, katalase positif dan ornitin positif. Hasil dapat dilihat pada Tabel 3. Berdasarkan hasil pengamatan, diperoleh bahwa bakteri yang memiliki aktivitas kemampuan QQ terhadap $C$. violaceum yaitu isolat 6 memiliki kemiripan dengan genus Pseudomonas.

Tabel 3. Hasil Uji Biokimia

\begin{tabular}{ccc}
\hline No & Uji Biokimia & Hasil \\
\hline 1 & Kebutuhan Oksigen & Aerob \\
2 & Motilitas & $(+)$ \\
3 & Glukosa & $(-)$ \\
4 & Laktosa & $(-)$ \\
5 & Manitol & $(-)$ \\
6 & Maltosa & $(-)$ \\
7 & Sakarosa & $(-)$ \\
8 & Indol & $(-)$ \\
9 & Simon Sitrat & $(+)$ \\
10 & Oksidase & $(-)$ \\
11 & Katalase & $(+)$ \\
12 & Ornitin & $(+)$ \\
\hline
\end{tabular}

Rimpang kunyit yang digunakan pada penelitian ini adalah rimpang yang tidak terlalu muda ataupun tua. Sterilisasi permukaan dilakukan untuk mengeliminasi mikroorganisme lain yang terdapat di permukaan tumbuhan. Keberhasilan sterilisasi permukaan dilakukan untuk memastikan tidak adanya pertumbuhan bakteri selain bakteri endofit pada media NA. ${ }^{20}$ Hasil konfirmasi sterilisasi permukaan menunjukkan tidak adanya pertumbuhan bakteri pada media sehingga proses sterilisasi telah berhasil. Jika terdapat bakteri pada media konfirmasi maka bakteri tersebut bukan merupakan bakteri endofit. ${ }^{21}$

Isolasi bakteri endofit tanaman kunyit dilakukan dengan menggunakan media NA sebagai media pertumbuhan dan ditambahkan Nistatin untuk mencegah pertumbuhan jamur pada media. ${ }^{22}$ Bakteri yang tumbuh setelah 24 jam sejak penanaman potongan rimpang pada media NA akan diisolasi ke media NA yang lain dan 
dimurnikan untuk mendapatkan koloni tunggal dengan menggunakan metode cawan gores. Isolasi dilakukan untuk mendapatkan koloni bakteri murni yang memiliki morfologi yang sama karena berasal dari pembelahan satu sel yang sama.

Koloni bakteri yang sudah murni diamati morfologinya dengan melihat warna, bentuk, permukaan, dan tepi koloni. Hal ini dilakukan untuk mempermudah dalam melakukan proses pemurnian dengan membedakan karakteristik bakteri yang tumbuh secara makroskopis. Pengamatan morfologi sel dari koloni bakteri murni dilakukan dengan pewarnaan Gram dan pengamatan bentuk secara mikroskopis. Bakteri Gram negatif memiliki dinding sel dengan kandungan lipid yang tebal sehingga dapat menyerap pewarna kristal violet, namun ketika diberi alkohol kristal violet akan luntur karena dinding selnya yang paling banyak disusun oleh lipid, sehingga pada akhirnya dinding sel menyerap pewarna safranin yang menyebabkan hasil pewarnaan bakteri Gram negatif menjadi warna merah. Bakteri Gram positif memiliki dinding sel yang tersusun atas lapisan peptidoglikan yang tebal sehingga pada saat ditambahkan pewarna kristal violet maka warna ungu akan diserap meskipun setelah diberi alkohol dan safranin karena lapisan peptidoglikan yang tebal sehingga tidak dapat dilunturkan oleh alkohol.

Peremajaan bakteri $C$. violaceum dilakukan untuk memastikan bakteri uji yang akan digunakan merupakan bakteri $C$. violaceum dan murni tanpa kontaminasi dari mikroorganisme lainnya. Peremajaan juga dilakukan untuk mendapatkan bakteri yang aktif, karena bakteri yang sebelumnya disimpan di dalam lemari pendingin berada dalam kondisi tidak aktif. Kondisi tidak aktif membuat bakteri yang akan digunakan menjadi kurang optimal dalam menghasilkan enzim. ${ }^{23}$ Didapatkannya biakan yang baru dan muda diharapkan dapat berkembang biak dengan baik sehingga dapat digunakan sesuai dengan fungsinya dengan baik. ${ }^{24}$ Peremajaan dan pemastian bakteri uji dilakukan secara makroskopis dan mikroskopis. Berdasarkan hasil yang diperoleh dapat dipastikan bahwa bakteri uji benar merupakan $C$. violaceum dengan morfologi sel Gram negatif berbentuk basil dan morfologi koloni berwarna ungu, berbentuk irreguler, tepian bergelombang dan cembung. ${ }^{25}$

Koloni bakteri yang telah murni akan diinokulasikan ke media NB (Nutrient Broth) yang bertujuan untuk mendapatkan bakteri dalam jumlah banyak sehingga metabolit sekunder yang dihasilkan menjadi optimal. Penggunaan media cair bertujuan untuk mendapatkan biomassa dan senyawa bioaktif secara efektif dibanding dengan menggunakan media padat. Proses ini dilakukan selama 72 jam pada suhu ruang dikarenakan pada waktu tersebut bakteri tumbuh pada fase stasioner. Fase stasioner adalah saat dimana laju pertumbuhan bakteri sama dengan laju kematiannya. Keseimbangan pada jumlah keseluruhan bakteri ini terjadi dikarenakan adanya pengurangan derajat 
pembelahan sel yang dipengaruhi oleh berkurangnya kadar nutrisi dan terjadinya akumulasi produk toksik sehingga menghambat pembelahan sel. Bakteri endofit menghasilkan metabolit sekunder pada fase ini dan aktivitas metabolit sekunder bakteri sangat berperan dalam pembentukan zona hambat karena bakteri siap menyekresikan metabolitnya yang dapat digunakan sebagai QQ. Metabolit yang dihasilkan merupakan hasil dari kompetisi bakteri untuk mendapatkan nutrisi pada media NB agar dapat bertahan sehingga masing-masing bakteri menghasilkan senyawa metabolitnya. ${ }^{26,27}$

Screening kemampuan QQ terhadap $C$. violaceum dilakukan dengan menggunakan metode difusi cakram. Metode ini dilakukan dengan cara menempatkan bakteri Gram negatif endofit tanaman kunyit yang tumbuh pada media NB ke kertas cakram. Kertas cakram kemudian diletakkan pada media NA yang sebelumnya sudah dicampur dengan bakteri uji $C$. violaceum. Untuk mendapatkan hasil media diinkubasi pada suhu ruang dan waktu tertentu sehingga dapat diamati zona hambat yang terbentuk. Pada zona hambat yang terbentuk menunjukkan masih adanya pertumbuhan bakteri tetapi pigmen bakteri yang terlihat pada media menjadi memudar hal ini menunjukkan terjadinya mekanisme penghambatan QS atau yang disebut dengan QQ. Hal ini sesuai dengan pernyataan yang ada pada literatur sebelumnya bahwa penghambatan QS dapat dilihat dengan penghambatan warna bakteri C. violaceum tetapi tidak membunuh bakteri dan menghambat patogenesisnya sehingga pertumbuhan bakteri masih ditemukan. ${ }^{28}$

Kurkumin yang terdapat pada tanaman kunyit (Curcuma longa L.) diketahui memiliki efek QQ pada beberapa bakteri. ${ }^{12-}$ ${ }^{14}$ Kurkumin dapat menghambat produksi pigmen violacein yang dimediasi oleh $\mathrm{HHL}$ pada C. violaceum. ${ }^{29} \mathrm{HHL}$ ( $\mathrm{N}$-hexanoyl-Lhomoserine lactone) atau C6-HSL merupakan molekul sinyal yang diatur sintesisnya oleh gen tipe Cvil yang berperan dalam pembentukan pigmen violacein. ${ }^{30,31}$ Terdapat 14 isolat bakteri yang menunjukkan adanya zona hambat terhadap C. violaceum, hal ini dapat disebabkan oleh senyawa yang sama dengan yang dihasilkan oleh tanaman kunyit.

Berdasarkan hasil pengamatan morfologi koloni, morfologi sel dan uji biokimia didapatkan bahwa isolat bakteri yang memiliki kemampuan QQ paling potensial yaitu Isolat 6 termasuk ke dalam genus Pseudomonas. Genus ini memiliki bentuk batang dengan ukuran 0,5-1,0 x 1,5-5,0 $\mu \mathrm{m}$. Gram negatif, hampir seluruh spesiesnya motil, aerob, oksidase dapat negatif, dan katalase positif. Bakteri ini tersebar luas di alam. ${ }^{19}$

Pada penelitian sebelumnya, genus Pseudomonas juga ditemukan di tanaman kunyit putih. ${ }^{32}$ Pseudomonas termasuk ke dalam genus yang sering teridentifikasi sebagai endofit bersamaan dengan Bacillus, Paenibacillus, Sphingomonas dan Enterobacter. ${ }^{33}$ Ekstrak bakteri 
Pseudomonas aeruginosa diketahui dapat menurunkan produksi violacein pada $C$. violaceum. Hal ini menunjukkan bahwa ekstrak $P$. aeruginosa dapat mempengaruhi mekanisme QS pada $C$. violaceum dengan menurunkan produksi violacein. ${ }^{34}$ Pseudomonas strain PAI-A dan Pseudomonas aeruginosa PAO1 diketahui memiliki $A H L$ acylase yang dikontrol oleh gen pvdQ dan unidentified acylase. ${ }^{35} \mathrm{AHL}$ acylase merupakan salah satu enzim pendegradasi AHL yang bekerja dengan menghidrolisis ikatan amida pada AHL yang berperan dalam proses QS. ${ }^{36}$ AHL acylase berpotensi memodulasi perilaku bakteri dengan mengganggu sistem QS. Sebuah penelitian menunjukkan bahwa menurunnya akumulasi AHL dapat mempengaruhi faktor produksi virulensi dan motilitas bakteri. ${ }^{37,38}$

Keragaman bakteri endofit pada tanaman obat yang sering dibudayakan dan digunakan masyarakat diketahui sangat tinggi. Dengan didapatkannya berbagai macam isolat bakteri dari tanaman kunyit dengan kemampuannya yang dapat menghasilkan senyawa bioaktif maka diperlukan eksplorasi keragaman dan potensi yang dimiliki bakteri endofit tanaman kunyit untuk memberikan peluang ditemukannya spesies berpotensi lainnya agar dapat menjadi penghasil senyawa aktif untuk obat baru tanpa harus mengambil langsung bagian dari tanaman.

Pada beberapa bakteri patogen, QS memiliki peran penting dalam regulasi produksi faktor virulensi yang sering kali menentukan keberhasilan infeksi pada inang. Oleh karena itu, penghambatan QS atau yang dikenal dengan QQ menyebabkan bakteri menjadi kurang virulen dan hal ini dapat dijadikan sebagai strategi prospektif dalam pengembangan obat baru yang akan mengurangi resistensi. ${ }^{39}$

\section{SIMPULAN}

Bakteri Gram negatif endofit tanaman kunyit (Curcuma longa L.) memiliki kemampuan QQ terhadap bakteri uji $C$. violaceum. Sebanyak 14 isolat bakteri Gram negatif endofit tanaman kunyit (Curcuma longa L.) yang berhasil diisolasi memiliki kemampuan QQ terhadap $C$. violaceum dengan diameter zona hambat berkisar antara 6,5-13,5 mm. Identifikasi karakter bakteri Gram negatif endofit yang memiliki kemampuan QQ paling potensial yaitu isolat 6 , berdasarkan morfologi sel, morfologi koloni dan uji biokimia dapat digolongkan ke dalam genus Pseudomonas.

\section{DAFTAR PUSTAKA}

1. Tortora GJ, Funke BR, Case CL. Microbiology: An introduction. 10th ed. California: Benjamin \& Cummings; 2010.

2. Kabir AH, Roy AG, Alam MF, Islam R. Detection of quorum sensing signals in Gram-negative bacteria by using reporter strain CV026. Not Sci Biol. 2010; 2(4):72-5. doi: 10.15835/nsb244863. 
3. Yang L, Liu Y, Sternberg C, Molin S. Evaluation of enoyl-acyl carrier protein reductase inhibitors as Pseudomonas aeruginosa quorum-quenching reagents. Molecules. 2010; 15(2):780-92. doi: 10.3390/molecules15020780.

4. Deep A, Chaudhary U, Gupta V. Quorum sensing and bacterial pathogenicity: From molecules to disease. J Lab Physicians. 2011; 3(1):4-11. doi: 10.4103/0974-2727.78553.

5. May AL, Eisenhauer ME, Coulston KS, Campagna SR. Detection and quantitation of bacterial acylhomoserine lactone quorum sensing molecules via liquid chromatography-isotope dilution tandem mass spectrometry. Anal Chem. 2012; 84(3):1243-52. doi: 10.1021/ac202636d.

6. Krishnan T, Yin WF, Chan KG. Inhibition of quorum sensing-controlled virulence factor production in Pseudomonas aeruginosa PAO1 by ayurveda spice clove (Syzygium aromaticum) bud extract. Sensors. 2012; 12(4):4016-30. doi: 10.3390/s120404016.

7. Rukayadi Y, Hwang JK. Pencegahan quorum sensing: Suatu pendekatan baru dalam mengatasi infeksi bakteri. Medicinus. 2009; 22(1):22-7.

8. Kalia, Chandra V. Quorum sensing inhibitors: An overview. Biotechnol Adv. 2013; 31(2):224-45. doi: 10.1016/j.biotechadv.2012.10.004.

9. Yang $\mathrm{CH}$, Li YH. Chromobacterium violaceum infection: A clinical review of an important but neglected infection. J Chin Med Assoc. 2011; 74(10):435-41. doi: 10.1016/j.jcma.2011.08.013.

10. Skogman ME, Kanerva S, Manner S, Vuorela PM, Fallarero A. Flavones as quorum sensing inhibitor identified a newly optimized screening platform using Chromobacterium violaceum as reporter bacteria. Molecules. 2016; 21(9):E1211. doi: 10.3390/molecules21091211.

11. Tiwit W, Bustanussasalam B, Harmastini S, Partomuan S. Isolasi dan identifikasi kapang endofit dari tanaman kunyit (Curcuma longa L.) sebagai penghasil antioksidan. Biopropal Industri. 2016; 7(1):9-16.

12. Bacha K, Tariku Y, Gebreyesus F, Zerihun S, Mohammed A, Weiland-Bräuer N, Mulat M. Antimicrobial and anti-quorum sensing activities of selected medicinal plants of Ethiopia: Implication for development of potent antimicrobial agents. BMC Microbiol. 2016; 16(1):139. doi: 10.1186/s12866-016-0765-9.

13. Nazzaro F, Fratianni F, Coppola R. Quorum sensing and phytochemicals. Intl J Mol Sci. 2013; 14(6):12607-19. doi: 10.3390/ijms140612607.

14. Gottardi D, Bukvicki D, Prasad S, Tyagi AK. Beneficial effects of spices in food preservation and safety. Front Microbiol. 2016; 7:1394. doi: 10.3389/fmicb.2016.01394.

15. Maehara S, Simanjuntak P, Kitamura C, Ohashi K, Shibuya H. Cinchona alkaloids are also produced by an endophytic filamentous fungus living in cinchona plant. Chem Pharm Bull. 2011; 59(8):1073-4. doi: $10.1248 / c p b .59 .1073$.

16. Haryono. Ayo mengenal tanaman obat. Jakarta: Badan Penelitian dan Pengembangan Pertanian Kementrian Pertanian; 2012.

17. Sulistiyani TR. Keragaman Bakteri Endofit Tanaman Kunyit Putih (Curcuma zeodaria) dan Toksisitasnya terhadap Embrio Ikan Zebra. Bogor: Institut Pertanian Bogor; 2014.

18. Fitriyah D. Karakterisasi Bakteri Penghasil Asil Homoseril Lakton Laktonase dan Asilase yang diisolasi dari Lahan Pertanian [Tesis]. Bogor: Institut Pertanian Bogor; 2015.

19. Holt JG, NR Krieg. Bergey's manual of determinative bacteriology. 9th ed. Baltimore: Williams \& Wilkins; 2000. p.187. 
20. Agusta A. Biologi dan kimia jamur endofit. Bandung: ITB; 2009. p.115-8.

21. Munif A, Hipi A. Potensi bakteri endofit dan rhizosfer dalam meningkatkan pertumbuhan jagung. Prosiding Seminar National Serelia. Bogor: Institut Pertanian Bogor; 2012.

22. Dwidjoseputro. Dasar-dasar mikrobiologi. Jakarta: Djambatan; 2010.

23. Charlena, Haris A, Karwati. Degradasi Hidrokarbon pada Tanah Tercemar Minyak Bumi dengan Isolat A10 dan D8. Prosiding Seminar Nasional Sains II. Bogor: Institut Pertanian Bogor; 2009.

24. Mas'ud F. Media, Isolasi, Sterilisasi, Peremajaan, dan Penyimpanan Mikroba; 2013. Diunduh dari: https://www.scribd.com/presentation/100436268/Media-Isolasi-Sterilisasi-Peremajaan-Dan

25. Vasconcelos ATR, de Almeida DF, Hungria M, Guimarães CT, Antônio RV, Almeida FC, et al. The complete genome sequence of Chromobacterium violaceum reveals remarkable and exploitable bacterial adaptability. Proc Nat Aca Scien of U S A. 2003; 100(20): 11660-11665. doi: 10.1073/pnas.1832124100.

26. Pratiwi ST. Mikrobiologi farmasi. Jakarta: Erlangga; 2009.

27. Fitriyah D, Jose C, Saryono. Skrining aktivitas antimikroba dan uji fitokimia dari kapang endofitik tanaman dahlia (Dahlia variabilis). J Ind Che Acta. 2009; 3(2):50-5.

28. Ardani YB. Uji aktivitas antibakteri dan anti-quorum sensing fraksi dari ekstrak etanol daun salam (Eugenia polyantha Wight). [Skripsi]. Surabaya: Fakultas Farmasi, Universitas Katolik Widya Mandala; 2013.

29. Packiavathy IA, Priya S, Pandian SK, Ravi AV. Inhibition of biofilm development of uropathogens by curcumin-an anti-quorum sensing agent from Curcuma longa. Food Chem. 2014; 148:453-60. doi: 10.1016/j.foodchem.2012.08.002.

30. McClean KH, Winson MK, Fish L, Taylor A, Chhabra SR, Camara M, et al. Quorum sensing and Chromobacterium violaceum: Exploitation of violacein production and inhibition for the detection of $\mathrm{N}$-acylhomoserine lactones. Microbiology. 1997; 143(Pt 12):3703-11. doi: 10.1099/00221287-143-12-3703.

31. Morohoshi T, Kato M, Fukamachi K, Kato N, Ikeda T. N-Acylhomoserine lactone regulates violacein production in Chromobacterium violaceum type strain ATCC 12472. FEMS Microbiol Lett. 2008; 279(1):124-30. doi: 10.1111/j.1574-6968.2007.01016.x.

32. Sulistiyani TR, Lisdiyanti P, Lestari Y. Population and diversity of endophytic bacteria associated with medicinal plant Curcuma zedoaria. Microbiology Indonesia. 2014; 8(2):64.

33. Miller KI, Qing C, Sze DM, Roufogalis BD, Neilan BA. Culturable endophytes of medicinal plants and the genetic basis for their bioactivity. Microb Ecol. 2012; 64(2):431-49. doi: 10.1007/s00248012-0044-8.

34. Fitriani A, Ayuningtyas DP, Kusnadi. Inhibition of quorum sensing in Chromobacterium violaceum CV026 by violacein produced by Pseudomonas aeruginosa. Journal of Experimental Biology and Agricultural Sciences. 2016; 4(1):103-8. doi: 10.18006/2016.4(1).103.108.

35. Huang JJ, Han JI, Zhang LH, Leadbetter JR. Utilization of acylhomoserine lactone quorum signals for growth by a soil pseudomonad and Pseudomonas aeruginosa PAO1. Appl Environ Microbiol. 2003; 69(10):5941-9. doi: 10.1128/aem.69.10.5941-5949.2003.

36. Uroz S, Dessaux Y, Oger P. Quorum sensing and quorum quenching: The yin and yang of bacterial communication. Chembiochem. 2009; 10(2):205-16. doi: 10.1002/cbic.200800521. 
37. Lin $\mathrm{YH}, \mathrm{Xu} \mathrm{JL}$, Hu J, Wang LH, Ong SL, Leadbetter JR, Zhang LH. Acylhomoserine lactone acylase from Ralstonia strain XJ12B represents a novel and potent class of quorum-quenching enzymes. Mol Microbiol. 2003; 47(3):849-60. doi: 10.1046/j.1365-2958.2003.03351.x.

38. Leadbetter JR, Greenberg EP. Metabolism of acylhomoserine lactone quorum-sensing signals by Variovorax paradoxus. J Bacteriol. 2000; 182(24):6921-6. doi: 10.1128/JB.182.24.69216926.2000.

39. Utari PD, Vogel J, Quax WJ. Deciphering physiological functions of AHL quorum quenching acylases. Front Microbiol. 2017; 8:1123. doi: 10.3389/fmicb.2017.01123. 